\title{
The Role of Information Communication Technology (ICT) in Shifting Informal MSMES to Formal MSMES in Indonesia: The Initial Trigger Model
}

\author{
$1^{\text {st }}$ Ernie Hendrawaty ${ }^{1}, 2^{\text {nd }}$ Kevin Joan ${ }^{2}, 3^{\text {rd }}$ Dimas Putra Adzie $^{3}$ \\ \{ernie.hendrawaty@feb.unila.ac.id ${ }^{1}$, kevinjoan@gmail.com ${ }^{2}$,dimasadzie123@gmail.com ${ }^{3}$ \} \\ Faculty of Economics and Business, University of Lampung, Indonesia ${ }^{1,2,3}$
}

\begin{abstract}
This paper attempts to offer an alternative initial trigger model in developing and shifting informal MSMEs to formal MSMEs. The extant literature on the (i) financial report, marketing, human resources, and financing constraints faced by MSMEs in developing their business and (ii) ICT has been reviewed critically and used to propose an alternative model in developing MSMEs. The paper has developed ICT's Model as a strategy to shift informal MSMEs to formal MSMEs in Indonesia. This model is expected to provide Directorate General of Taxation to meet their liquidity constraint in developing and shifting informal MSMEs. It is also engaged in the involvement of the MSMEs platform based on ICT. The paper is based on conceptual explorations of literature in the area of MSMEs and ICT. This paper is conceptual, so it did not employ any empirical analysis. The findings of this paper will provide the Directorate General of Taxation with an alternative model in developing and shifting informal MSMEs. The present study also has implications for government and policymakers. By involving ICT's, it helps the government to increase the number of formal MSMEs for the higher tax revenue in Indonesia.
\end{abstract}

Keywords: Business Development Services, Formal Business, ICT, MSMEs, TAM

\section{Introduction}

Micro, small, and medium-sized enterprises (MSMEs) have an essential role in a nation's development. MSMEs actively participate in the distribution of Indonesia's development and has a strategic role in supporting the national economy [1]. Ministry of Cooperatives and Small Medium Enterprises (SMEs) stated that MSMEs represent $99,9 \%$ of all the business units in Indonesia, contributed approximately 4.869,5 Trillion Rupiahs, or 59.08\% on National GDP and hired for labors up to $97.22 \%$. However, a tremendous potential of MSMEs is not fully optimized yet due to some constraints because only 397 thousand businesses paid annual notification letters (SPT)[2]. It indicates only $0.67 \%$ of MSMEs paid taxes from 59 million existing MSMEs, and there are still more than 58 million MSMEs who are involving in the informal sector. Ministry of Finance has tried to initiate Business Development Services (BDS) as a catalysator to help MSMEs. BDS is a service with a particular task in the form of guidance for MSMEs towards the realization of business development. The presence of BDS is expected to improve professionalism, quality, and solution to the problems often faced by MSMEs. It means that BDS is a real need for MSMEs to improve their business[3]. Nevertheless, BDS had not brought a significant impact on the development of MSMEs. BDS only tends to strengthen its management and focus more on MSMEs whose accounting systems are neat. BDS should not only strengthen institutions but rather serve MSMEs, especially new players who still have terrible management. Refers to the strategic role of MSMEs, the law regarding Government Act (PP) number 23 of 2018 regarding income 
tax that has been replaced for Government Act (PP) number 46 of 2013, whereas the final income tax rate $(\mathrm{PPh})$ was reduced to $0.5 \%$ for MSMEs actors, is an appropriate policy to remind that so far there are still many MSMEs who are trading in the informal sector. The regulation aims to encourage MSMEs to play an active role in formal economic activities by providing easy access to MSMEs actors in paying taxes and tax impositions equally. By implementing, it is expected that the tax burden for MSMEs actors getting smaller than before; hence, MSMEs actors have a higher economic capacity to develop businesses and make investments. However, the policy leads to a new problem, for example, reducing half of MSMEs' tax revenues. Therefore, the big question is how to optimize the existing MSMEs? Does ICT's have a significant role in improving the performance of MSMEs hence shifting informal MSMEs to formal MSMEs?

\section{Literature Review}

\subsection{Technology Acceptance Model}

TAM (Technology Acceptance Model) is a model built to analyze the factors that influence acceptance to use of technology. TAM aims to describe the individual acceptance of the system technology. TAM constantly explain the determinant of perceived technology by the customer [4]. It has divided by two factors such as; Perceived Usefulness and Perceived Ease of Use.

\subsubsection{Perceived Usefulness}

Perceived usefulness is described as the degree to which a person believes that using a particular system would enhance his or her job performance [5].

\subsubsection{Perceived Ease of Use}

Perceived Ease of Use is defined as the extent of people who agree and ensure that system is easy to use. found that two factors of TAM (Perceived Usefulness and Perceived Ease Of Use) had a strong influence on the intention to adopt internet banking that used by MSMEs.

\subsection{Theory of Information, Communication, and Technology (ICT's)}

Actor-Network Theory (ANT) was received to comprehend both the developmental and rising nature of ICT. ANT endeavors to address the job that innovation plays in a social setting and the procedure by which innovation reciprocally impacts the social setting after some time. ANT ideas have likewise been utilized to examine innovation reception and advancement. From one perspective, considered innovation improvement and selection by drawing on ANT ideas of engraving, interpretation, and surrounding to analyze the procedures engaged with the advancement of web programs. Further, ICT's are an essential tool to upgrade the profitability of firms [6]. Advancements (ICTs), especially the utilization of the Internet to lead a business, have changed how individuals work together. For MSMEs, the Internet is accepting to be the most cost-proficient part to assist organizations with increasing more significant markets and rival more prominent organizations in pulling in their items, administrations, and data [4], [7].

\subsection{ICT Development and Its Potential Use}

The development of Information, Communication, and Technology (ICT) in Indonesia, which continues to increase every year, is an appropriate answer to this paper's big questions. The Indonesian Internet Service Providers Association (APJII) stated that the number of internet users in Indonesia reached 143.26 million in 2017 or approximately 54.68 percent of Indonesia's population. If further classified by age category, internet users in Indonesia are dominated by productive age groups with the age range 1954 years through a penetration rate of $79.07 \%$, where $48.25 \%$ percent is concentrated in the rural areas [8]. Moreover, The Fiber Optic (Palapa Ring) and Base Transceiver Station (BTS) projects that reach the 3T (lagging, front and outermost) areas that are targeted to be completed in early 2019 will support better 
internet access in Indonesia [9]. Looking at these data, this can be an excellent opportunity to shift informal MSMEs to formal MSMEs especially in rural areas[10], [11]

\subsection{Framework Model}

The initial trigger model is reflected in this framework;

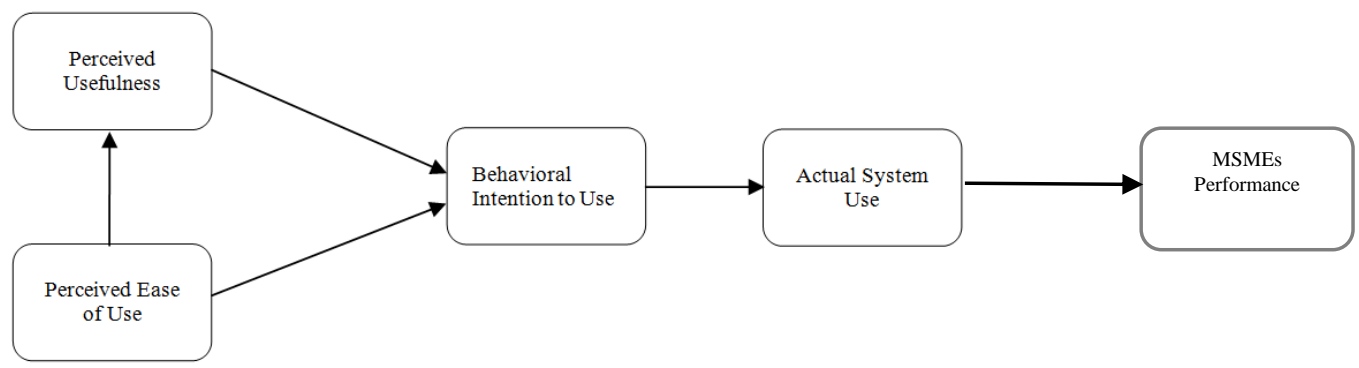

LaMikro is an application that launched by the Ministry of Cooperatives and Small and Medium Enterprises (SMEs) to assist micro-entrepreneurs in making financial reports hence they can increase their business productivity. Ease of use of a technology service will increase productivity and bring benefits to the users; hence the users tend to apply technology services continually. If MSMEs get LaMikro services optimally and are easy for them to use (i.e. convenience and completeness of features), then it will increase the productivity of MSMEs players and tend to apply LaMikro services continually. The intention to use of LaMikro App is not to perform expectedly (only $0.97 \%$ of MSMEs). The usefulness of LaMikro app is not to address the complex problem of MSMEs. Thus, this research will propose the gap to improve the intended use of the LaMikro App by providing creative features such as; bookkeeping, consultation, access to the global market, credit access, business development, and complaints.

\section{METHODOLOGY}

The analysis used in this paper is a literature study with the primary references for writing this paper sourced from journals, books, and news from international and national media. This paper mostly uses data derived from government statistics and extensive research as the primary foundation in analyzing problems and inspiring the solutions offered.

\section{PROPOSED MODEL}

The authors offer an idea of collaboration between the Directorate General of Taxes (DGT), BDS, Microfinance Institutions (MFIs), and Centers for MSMEs by utilizing information technology and the internet liaison media to develop MSMEs and increase the number of formal business in Indonesia. This idea consists of five essential elements, such as: Directorate General of Taxation as an institution to collect taxes for the improve the country's welfare, BDS as the main actor to assist MSMEs, MFIs as sources of MSME loans, and The center of MSMEs is the center of business activities, assistance, and distribution of micro-credit for MSMEs, MSME actors as objects in implementing this strategy.

The development and empowerment of MSMEs is the main objective in this idea to encourage MSMEs that have been engaging in the informal sector towards the formal sector. Besides to these five essential elements, there is a supporting element that crucial roles, such as; the Ministry of Trade (Kemendag), which will connect MSMEs to the global market. To implement this idea, a collective effort from various parties is needed synergistically and comprehensively. Close relations, mutual support, and symbiosis of mutualism between the five elements will affect the level of development of MSMEs. The five main elements above have different capacities and entities but have the same vision in carrying out their roles. Furthermore, the role of each of the elements is presented in the following figure. 


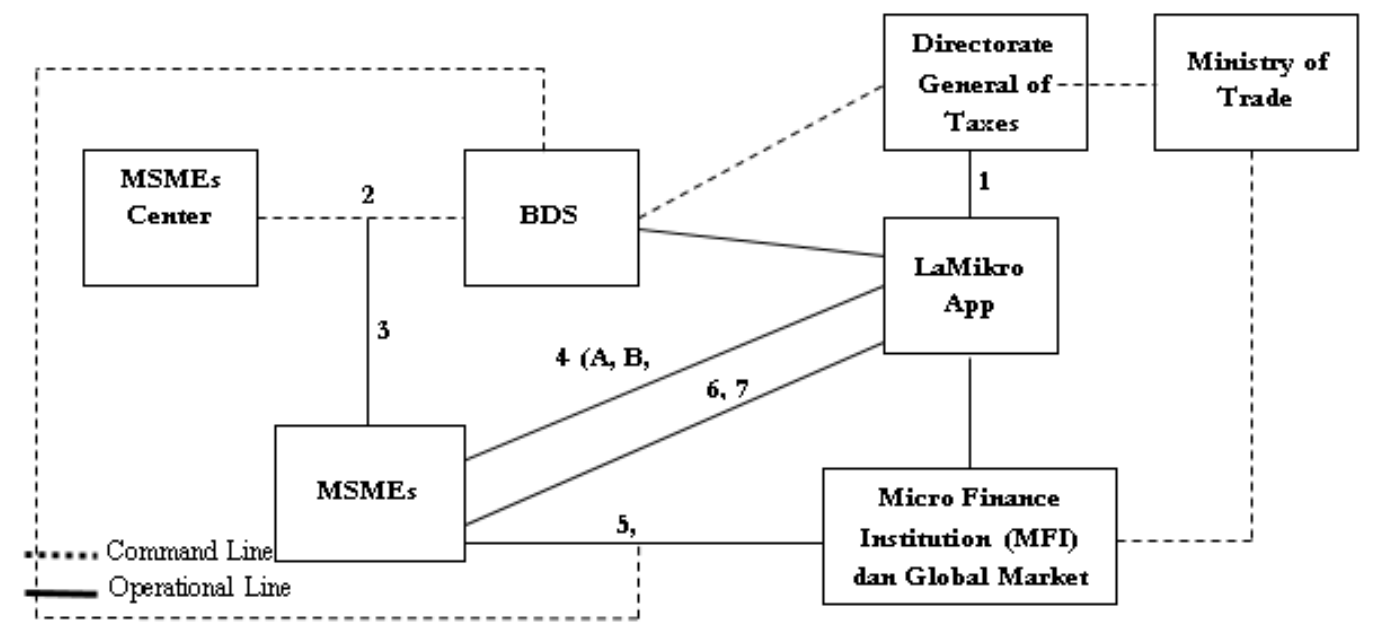

Figure 1. Strategic Scheme for Optimization Business Development Services (BDS)

(Source: The Author)

The collaboration mechanism for the ideas above is explained as follows:

Firstly, updating the LaMikro application service; hence it does not only function as a financial report bookkeeping application. It can function as a means of a) financial report/bookkeeping, b) tax payment, c) consultation, d) access to credit, e) access to a global market, f) business evaluation, and g) complaints. Secondly, BDS collaborates with MSMEs centers to collect data on all MSMEs around the Center for MSMEs, both formal and informal businesses. Thirdly, BDS visits the MSMEs actors concerned to assist in the development of these MSMEs. Fourthly, there are some recommendations that we proposed to improve LaMikro Application.

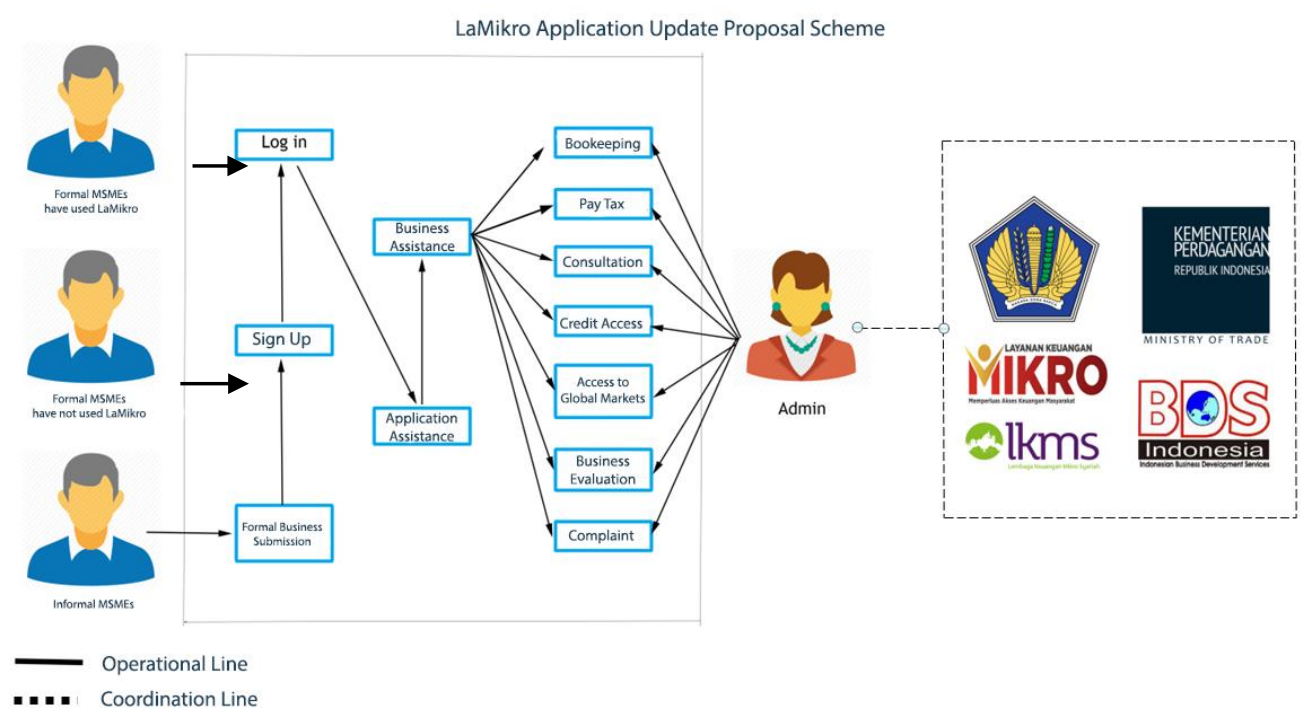

Figure 2. Proposed LaMikro Application Update Scheme (Source: The Author) 
For formal MSMEs that have used the LaMikro application service, BDS will help the development of business through business and financial management consultations, business evaluation, tax payments, marketing access to the global market, ease of credit to MFIs or commercial banks if it requires a more significant amount of credit with LaMikro application. For formal MSMEs that have not used the LaMikro application service, BDS will assist businesses in the registration and operation of the LaMikro application until business operators can operate adequately. Besides, BDS will help develop business units through business and financial management consultations, business evaluation, tax payments, marketing access to the global market, ease of credit to MFIs, or commercial banks if it requires a more significant amount of credit with LaMikro application. For informal MSMEs, BDS will assist businesses in formal business registration hence they can be given credit as additional capital and registration for their business and operation of the LaMikro application until businesses can operate adequately. Additionally, BDS will help the development of business units through business and financial management consultations, business evaluation, tax payments, marketing access to the global market, ease of credit to MFIs, or commercial banks if it requires a more significant amount of credit with LaMikro application. Fifthly, ease of access to credit to MFIs and access to the marketing of global markets using gearing ratios. The magnitude of loans that can be borrowed and how full access to global marketing will significantly improve the level of compliance of business actors in their tax payments and BDS evaluations of business actors. Sixthly, in the money distribution process, MSMEs will create accounts from MFIs that can be accessed through the LaMikro application. Seventhly, evaluate the performance and development of MSMEs by BDS and periodically evaluate the performance of BDS by MSME. Eighthly, payment of MSMEs loan installments to MFIs. These strategies will help BDS reach formal MSMEs actors who have not paid taxes or informal MSMEs players to develop their business sustainably and adequately. Therefore, it will encourage MSMEs that have been moving in the informal sector to move towards the formal sector.

\subsection{Strategic Steps in Implementing Ideas}

This idea is a breakthrough to support Government Act number 23 of 2018 by optimizing BDS and working with related institutions. The strategic steps are explained as follows:

Short-term: conditioning, developing strategic of ideas, and arranging infrastructure. Then, for mediumterm: doing the pilot project, evaluating the pilot project, improving ideas, and implementing ideas in a limited scope. For long-term: evaluating and improving the quality of ideas regularly, further collaborating with stakeholders to optimize more productive and efficient ideas in implementing ideas in the broader scope.

\subsection{The Significance of Model}

From the development of the model above shows that ICT can reach, empower, and shift informal MSMEs to formal MSMEs. Furthermore, this model can significantly impact the Director-General of Taxes, MSME actors, and economics as well as academic and theory development.

\subsubsection{Impact on the Directorate General of Taxation}

The proposed model will reach informal MSMEs that have not been engaged so far, then empower these MSMEs related to general and specific problems that are faced by informal MSMEs, these are quality human resources, funding, marketing, recording, and financial reporting. It aims to shift informal MSMEs to formal MSMEs. Hence, they get better and comprehensive state facilities related to the problems of MSMEs, besides, if informal MSMEs have shifted towards formal MSMEs, it will increase tax revenues and increase regular MSMEs income. 


\subsubsection{Impact on MSMEs Expertise and Economy}

The proposed model will provide convenience for the public, especially MSME players, both informal and formal, to face common obstacles that usually occur in MSMEs in terms of quality human resources, funding, marketing, recording to financial reporting.

\subsubsection{Impact on Academia}

The proposed model appends the existing literature in the scope of studies related to MSMEs and ICT. This study describes the existing literature related to the use of ICT in reaching, empowering, and shifting informal MSMEs to formal MSMEs, especially in Indonesia. MSMEs have extraordinary potential and have a strategic role in efforts to build the nation's economy.

\section{CONCLUSION}

This study has shown that there is a broad scope of MSMEs, which is informal. Directorate General of Taxation faces the problem of fulfilling the liquidity to develop and shift informal MSMEs to formal MSMEs. Lack of utilization ICT's is considered to be the most pointers stirring their qualification to develop and shift informal MSMEs to formal MSMEs, even though there is a BDS as an institution that assists MSMEs. This study has implications for the government and policymakers. By involving ICT's, it helps the government to increase the number of formal MSMEs for the higher tax revenue in Indonesia through business consultations, tax payments, marketing access to the global market, and also ease of credit with LaMikro application.

\section{LIMITATIONS AND RECOMMENDATIONS}

This study has three limitations. Firstly, this study is only for Indonesia. Secondly, the lack of information about MSMEs and BDS conditions in each region in Indonesia. Thirdly, it is a conceptual paper. Therefore, there is no experimental analysis directed. To enhance this model, the recommendations that we suggest are: (i) the advanced model should be ratified through surveys and interviews to measure stakeholders' intentions. (ii) mapping the model by adjusting the condition and situation of MSMEs and BDS in each region in Indonesia to optimize the models offered.

\section{References}

[1] L. Chairoel, S. Widyarto, and V. Pujani, "ICT adoption in affecting organizational performance among Indonesian SMEs," Int. Technol. Manag. Rev., vol. 5, no. 2, p. 82, 2015, doi: 10.2991/itmr.2015.5.2.3.

[2] A. A. Herlambang, "Dampak Sosialisasi Perpajakan Bagi Pemilik Usaha Pada Sektor Usaha Mikro Dan Kecil: Faktor Pemahaman Dan Kepatuhan Pajak," Ultim. Account., vol. 10, no. 1, pp. 77-95, 2018, doi: 10.31937/akuntansi.v10i1.834.

[3] R. Sudayanto, Ragimun, dan Rahma, "Starategi pemberdayaan UMKM menghadapi pasar bebas ASEAN," Univ. Negeri Jember, vol. 1, no. UMKM menghadapi pasar bebas ASEAN, p. 1, 2011, [Online]. Available: http://jurnal.unpad.ac.id/sosiohumaniora/article/view/12249/6227.

[4] D. Tan, Internet-based ICT adoption: Demographic versus benefits, barriers, and adoption intention, vol. 34, no. 1. 2010.

[5] F. D. Davis, R. P. Bagozzi, and P. R. Warshaw, "User Acceptance of Computer Technology: A Comparison of Two Theoretical Models," Manage. Sci., vol. 35, no. 8, pp. 982-1003, 1989, doi: 10.1287/mnsc.35.8.982.

[6] T. Oliveira and M. F. Martins, "Information technology adoption models at Firm Level," Electron. J. Inf. Syst. Eval., vol. 14, no. 1, pp. 110-121, 2011.

[7] K. S. Tan, S. C. Chong, B. Lin, and U. C. Eze, "Internet-based ICT adoption among SMEs: Demographic versus benefits, barriers, and adoption intention," J. Enterp. Inf. Manag., vol. 23, no. 1, pp. 27-55, 2010, doi: 10.1108/17410391011008897.

[8] APJII, "Penetrasi \& Perilaku Pengguna Internet Indonesia Survey 2017," Teknopreneur, vol. 2018, no. 31 August 2018, p. Hasil Survey, 2017.

[9] Kominfo, "Kominfo Targetkan 5.000 BTS di Daerah Terpenci," Kominfo Targetkan 5.000 BTS 
di Daerah Terpenci, Jakarta, Jan. 2018.

[10] I. Zambon, M. Cecchini, G. Egidi, M. G. Saporito, and A. Colantoni, "Revolution 4.0: Industry vs. agriculture in a future development for SMEs," Processes, vol. 7, no. 1, 2019, doi: 10.3390/pr7010036.

[11] J. Lerche, "Labour Regulations and Labour Standards in India: Decent Work?," Glob. Labour $J$. , vol. 3, no. 1, 2012, doi: 10.15173/glj.v3i1.1111. 